\title{
Ciguatoxins in Fish
}

\author{
Contributor: , Tibor Pasinszki $^{1}$ \\ 1, Fiji National University; tibor.pasinszki@fnu.ac.fj
}

Version received: 13 August 2020

check for

updates

\section{Definition}

Ciguatoxins are very potent marine neurotoxins, that accumulate to toxic levels in edible fish in certain circumtropical areas, and are associated with ciguatera fish poisoning worldwide. Ciguatoxins are produced by specific benthic dinoflagellate species, enter the marine food chain via herbivorous fish and invertebrates, and eventually biotransformed in herbivorous, omnivorous, and carnivorous fishes to more poisonous forms. Ciguatoxins cause risks to human health at very low concentrations. To decrease the risk of ciguatera fish poisoning, it is important to know fishing areas with low risk of ciguatoxins, as well as to test fish tissue for toxins before consumption. Modern laboratories are using several detection techniques, such as mouse bioassay, cellbased assays, receptor-binding assays, antibody-based immunoassays, electrochemical methods, and analytical techniques, to obtain information about the total toxicity of fish tissue samples, as well as to identify toxins and to determine the toxin profile. State-of-the-art ciguatoxin detection involves the combination of a cell-based assay or receptor-binding assay to screen the total toxicity and liquid chromatography coupled with mass spectrometry to confirm toxins and provide toxin profiles.

Table of Contents [Hide]

\section{Introduction}

Ciguatera Fish Poisoning (CFP) is a foodborne disease which is associated with consumption of circumtropical fish that is contaminated with ciguatoxins (CTX). ${ }^{[1][2][3][4][5][6][7][8][9][10][1][12][13][14] ~ C T X s ~ a r e ~ c o l o r l e s s, ~ o d o r l e s s, ~ h e a t-s t a b l e, ~}$ and lipid-soluble compounds that cannot be detected by smell and cannot be destroyed by normal cooking. Although human intoxication by CTXs is very rarely fatal, CTXs can cause neurological, gastrointestinal, and cardiovascular symptoms depending on the type and amount of toxin ingested. CTXs are produced by specific benthic dinoflagellate species from the Gambierdiscus and Fukuyoa genera, from which G. polynesiensis in the Pacific Ocean and G. excentricus in the Atlantic Ocean exhibit the major threat to human health. CTXs are biotransformed into more potent CTX derivatives as they move along the marine food chain, and may accumulate to toxic levels in edible fish. CTXs are polyether-type compounds and their structure varies according to geographic distribution, what is the basis of their classification as Pacific Ocean (P-CTX), Caribbean Sea (C-CTX) and Indian Ocean (I-CTX) ciguatoxins. Due to their high toxicity, the safety limit for the most potent CTX (P-CTX-1) in fish tissue for human consumption has been set at $0.01 \mathrm{ng} / \mathrm{g}$ by both the European Food Safety Authority (EFSA) and United States Food and Drug Administration (US FDA); safety limit for other CTXs has been recommended as $0.01 \mathrm{ng}$ P-CTX-1 toxin equivalent/g fish tissue. ${ }^{[1] 15]}$ Due to their low concentration, the necessary extraction from the fish tissue and purification steps, and lack of reference materials, the identification and quantification of CTXs is challenging and requires laboratory operations.

\section{Ciguatoxins}

Multiple CTX congeners exist in fishes due to the metabolic modification of dinoflagellate toxins in fish. A relatively large number of CTXs (22 P-CTXs, 12 C-CTXs, and 6 I-CTXs) have been identified to date, but only about their half are structurally characterized (22 P-CTXs and 2 C-CTXs; Figure 1). Based on NMR and mass spectrometric studies,, 16$][17[18][19][20][21][22][23][24][25]$ the structure of CTXs is confirmed as contiguous cyclic ether rings aligned in a ladder-like fashion with varied chemical groups at the two termini of the rigid ladder in congeners. The toxicity of 
various CTX congeners are different. On the basis on their acute intraperitonial median lethal dose in mice, EFSA has adopted the following toxicity equivalency factors (TEFs) for CTXs: P-CTX-1= 1, P-CTX-2=0.3, P-CTX-3= 0.3, P-CTX$3 \mathrm{C}=0.2,2,3$-dihydroxy-P-CTX-3C $=0.1,51$-hydroxy-P-CTX-3C $=1, P-C T X-4 A=0.1, P-C T X-4 B=0.05, C-C T X-1=0.1$ and C-CTX-2=0.3.[1]
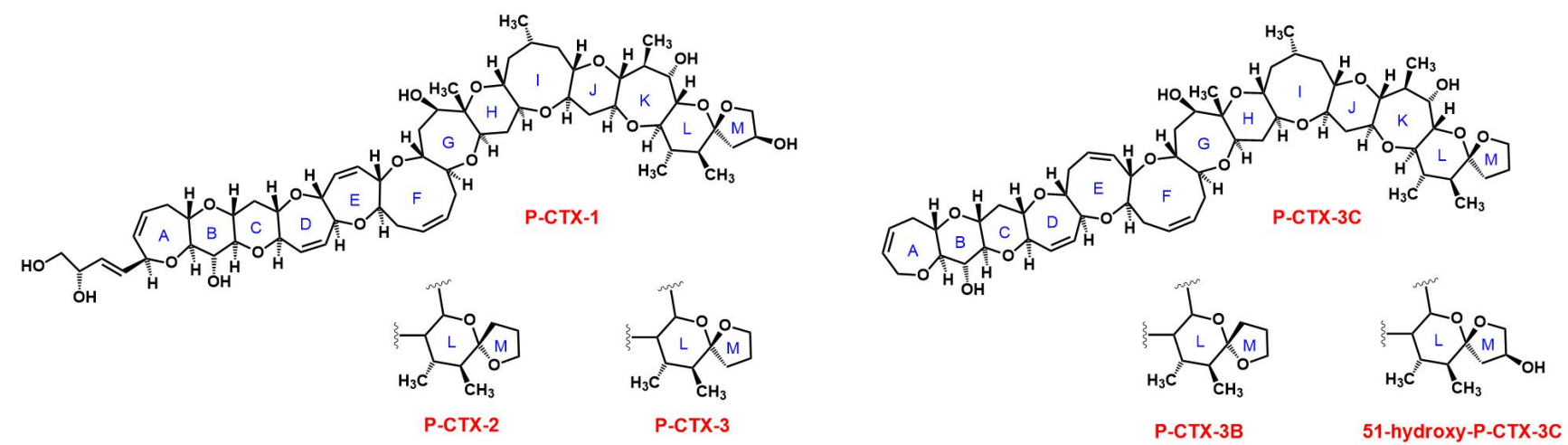

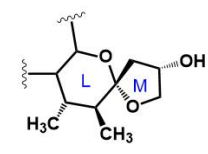

52-epi-P-CTX-1

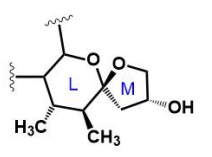

54-ері-P-СTX-1

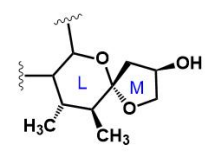

54-epi-52-epi-P-СTX-1

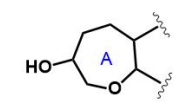

2,3-diH-2-OH-P-CTX-3C

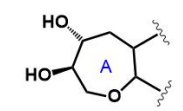

2,3-diH-2,3-diOH-P-CTX-3C
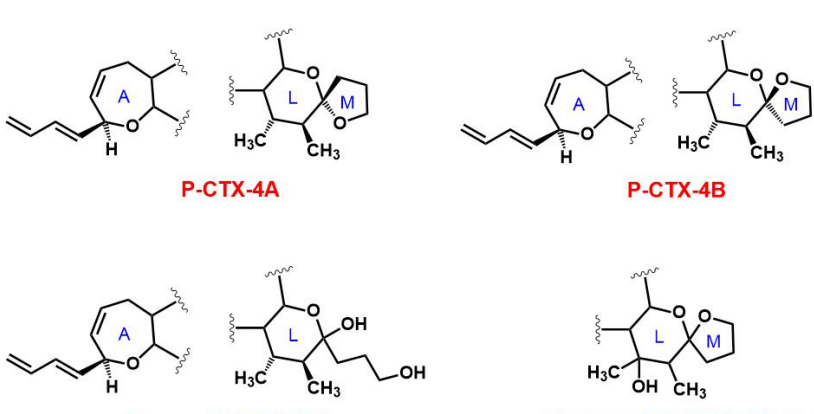

M-seco-P-CTX-4A/B

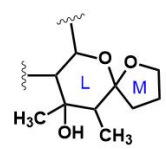

54-deoxy-50-OH-P-СTX-1

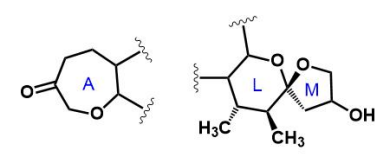

51-OH-2-охо-P-CTX-3C

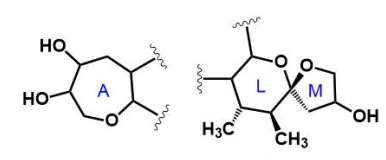

2,3-diH-2,3,51-triOH-P-CTX-3C

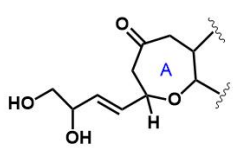

7-oxo-P-CTX-1

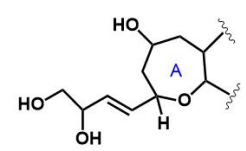

6,7-diH-7-OH-P-CTX-1

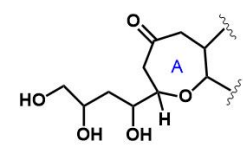

3,4-diH-4-OH-7-oxo-P-CTX-1

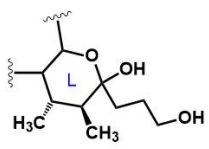

M-seco-P-CTX-3C

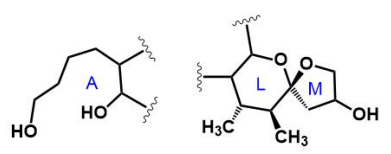

A-seco-2,3-diH-51-OH-P-CTX-3C
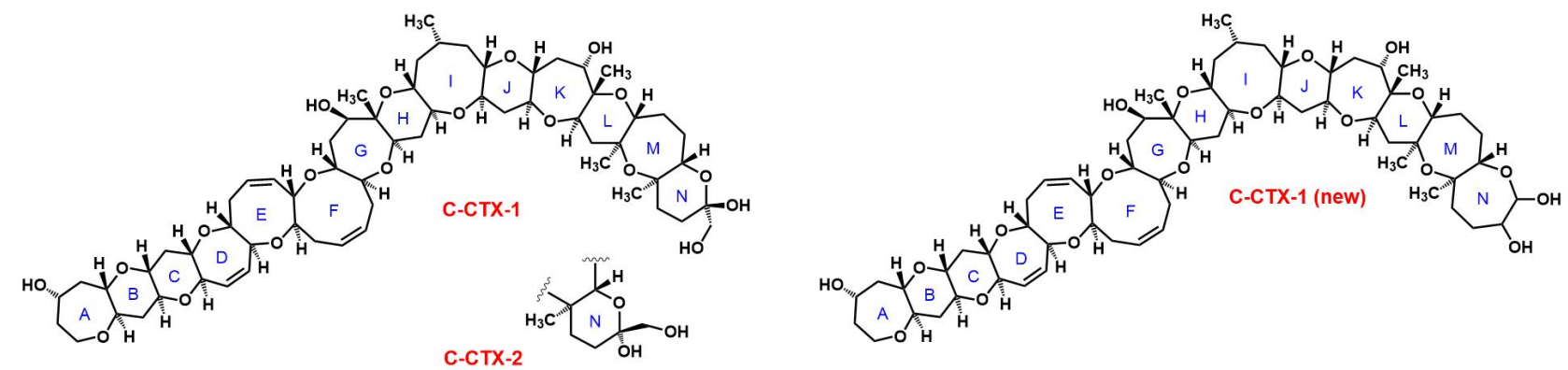

Figure 1. Structure of Pacific and Caribbean Ciguatoxins.

\section{Identification and Quantification of Ciguatoxins from Fish Tissue}

The identification and quantification of CTXs require their extraction and purification from fish tissue. In general, the extraction and purification process include multiple consecutive steps, such as: 1) extraction of cooked, freeze-dried or raw muscle tissue with a polar organic solvent; 2) purification of the extract by liquid-liquid partitioning; 3) defeating the extract by liquid-liquid partitioning; and 4) purification of the crude extract by solid-phase extraction (SPE). Several sample preparation protocols with considerable variation of consecutive purification steps exist in the literature. [26] 
These protocols are relatively complicated, not highly efficient, and their selection is not unambiguous. Validated extraction method does not exist to date.

Due to the danger of CTXs to human health, a wide variety of CTX detection methods have been developed to date, including animal mortality tests, biological methods (cell-based assays (CBA), receptor-binding assays (RBA), and immunoassays), and chemical methods (high-performance liquid chromatography (HPLC) coupled to tandem mass spectrometry (LC-MS/MS)). ${ }^{[14]}$ Many of these methods are not specific to CTXs, inadequate for quantification, or allow quantification of CTXs only with results expressed in "equivalent of a CTX standard". Animal mortality tests, except the mouse bioassay (MBA), are not used in laboratories any more due to their lack of specificity and ethical concerns. Cell-based assays are based on the toxic activity of fish tissue extracts on cultured cells, and receptor-binding assays are dependent on competitive binding between CTXs and a labeled brevetoxin compound for available receptor sites in a membrane preparation; therefore, CBA and RBA, and also MBA, reflect only the combined potency of related toxins in the extract mixture. CTX detection and quantification with immunoassays, such as Enzyme-Linked ImmunoSorbent Assays (ELISA), capillary electrophoresis (CE)-based immunoassays, and electrochemical immunosensors (ECS), are based on the application of a high-affinity antibody that is selective and specific for a CTX or a small number of CTXs. Immunoassays, therefore, provide specific information about the presence of selected CTXs in fish tissue. Biological CTX detection methods developed so far do not provide any information on the toxin profile. This latter requires the separation and separate identification of CTXs, and chemical methods, namely HPLC coupled to low or high resolution mass spectrometry, can fulfill this role. The main advantage of LC-MS/MS is that it is very specific and adequately sensitive to detect CTXs at clinically relevant toxin levels, and superior to any other techniques as the toxin confirmatory method. Currently, the most advanced methods for monitoring CTXs are based on the combination of biological and chemical methods into two steps by screening fish extract toxicity with sensitive functional assays first, followed by confirmation of the presence of CTXs via LC-MS/MS (Figure 2).

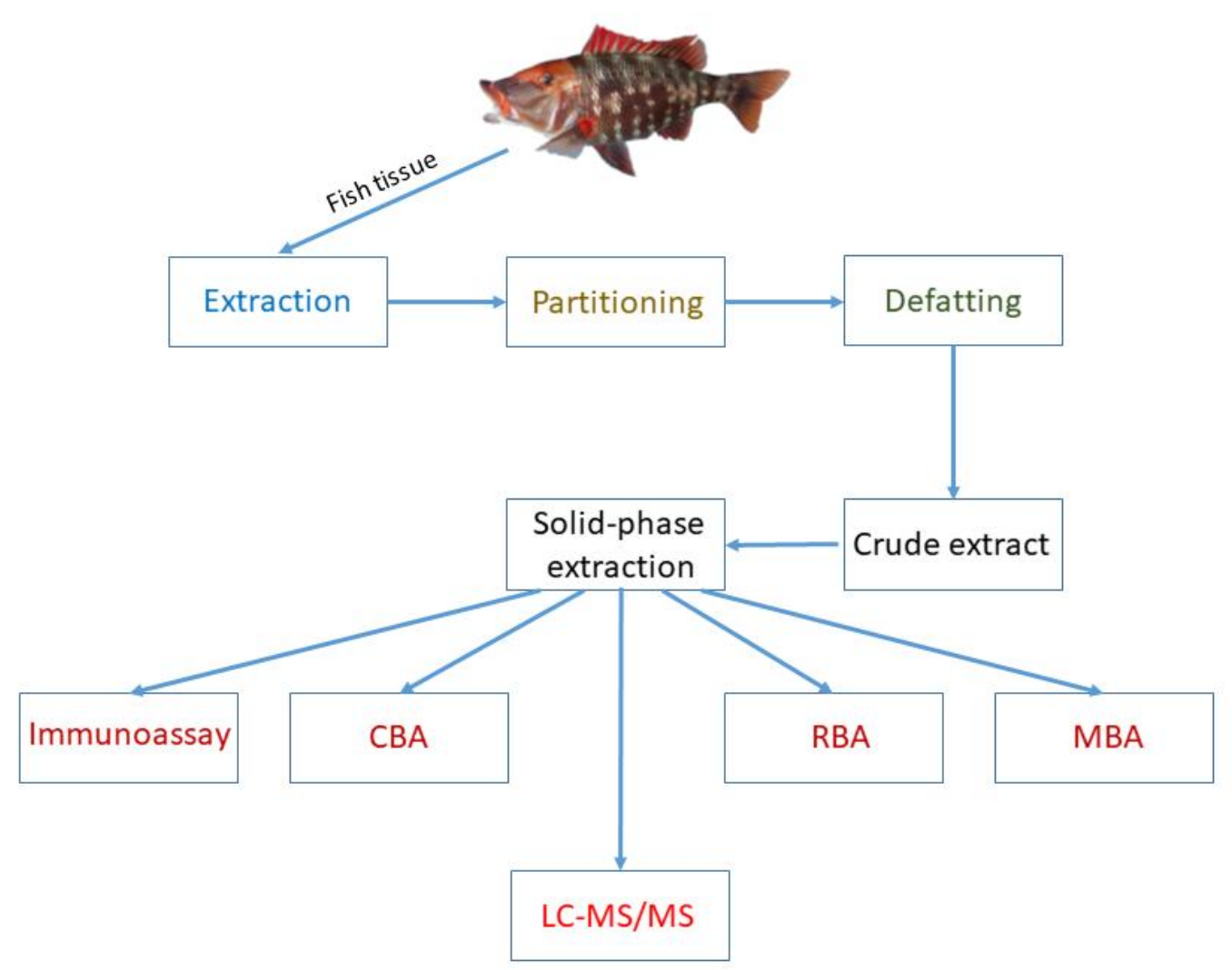

Figure 2. Extraction and Identification of Ciguatoxins.

\section{Conclusion}

CFP is a serious issue for communities in tropical regions that rely on fish for survival, and CFP has now become a global problem due to international travel, the worldwide seafood trade, and continuing expansion of the geographic areas of fish contaminated with CTXs. Several methods have been developed to date to evaluate the presence and 
amount of CTXs in fish tissue before consumption. In vivo whole-animal detection methods are now replaced byin vitro assays that have higher sensitivity, including cell-based assays, receptor-binding assays, immunoassays, and liquid chromatography tandem mass spectrometry. Present methods for CTX analysis are able to detect and quantify CTXs at clinically relevant levels, however, they are labor-intensive, expensive, time-consuming, and require laboratory facilities with well-trained operators. Further, these methods have not been properly validated to date, and standard CTX reference materials are not widely available, delaying widespread application of these methods. Currently, there is great demand for a portable and reliable CTX screening tool for private customers, and future developments are expected to move to this direction.

\section{References}

1. EFSA Panel on Contaminants in the Food Chain; Scientific Opinion on marine biotoxins in shellfish - Emerging toxins: Ciguatoxin group. EFSA Journal 2010, 8, 1627, doi:10.2903/j.efsa.2010.1627.

2. Lewis, R.J.; Vetter, I.. Ciguatoxin and Ciguatera. In Marine and Freshwater Toxins, Toxinology; P. Gopalakrishnakone et al., Eds.; Springer Science+Business Media: Dordrecht, 2016; pp. 71-92.

3. Inserra, M.; Lavrukhina, Y.; Jones, A.; Lewis, R.J.; Vetter, I.. Ciguatoxin Detection Methods and High-Throughput Assays. In Analysis of Food Toxins and Toxicants, 1st ed.; Wong, Y.-C., Lewis, R.J., Eds.; John Wiley \& Sons Ltd.: New Jersey, USA, 2017; pp. 469487.

4. Friedman, M.A.; Fleming, L.E.; Fernandez, M.; Bienfang, P.; Schrank, K.; Dickey, R.; Bottein, M.-Y.; Backer, L.; Ayyar, R.; Weisman, R.; et al.Watkins, S.Granade, R.Reich, A. Ciguatera Fish Poisoning: Treatment, Prevention and Management. Mar. Drugs 2008, 6, 456-479, 10.3390/md20080022.

5. Lewis, R.J.; The changing face of ciguatera. Toxicon 2001, 39, 97-106, 10.1016/S0041-0101(00)00161-6.

6. Friedman, M.A.; Fernandez, M.; Backer, L.C.; Dickey, R.W.; Bernstein, J.; Schrank, K.; Bernstein, J.; Stephan, W.; Weisman, R.; Kibler, S.; et al.et al. An Updated Review of Ciguatera Fish Poisoning: Clinical, Epidemiological, Environmental, and Public Health Management. Mar. Drugs 2017, 15, 72, 10.3390/md15030072.

7. Nicholson, G.M.; Lewis, R.J.; Ciguatoxins: Cyclic Polyether Modulators of Voltage-gated lon Channel Function. Mar. Drugs 2006, 4, 82-118, 10.3390/md403082.

8. Lehane, L.; Lewis, R.J.; Ciguatera: Recent advances but the risk remains. Int. J. Food Microbiol. 2000, 61, 91-125, 10.1016/S01681605(00)00382-2.

9. Dickey, R.W.; Plakas, S.M.; Ciguatera: A public health perspective. Toxicon 2010, 56, 123-136, 10.1016/j.toxicon.2009.09.008.

10. Juranovic L.R., Park D.L.. Foodborne Toxins of Marine Origin: Ciguatera. In Reviews of Environmental Contamination and Toxicology; Ware, G.W. , Eds.; Springer: New York, NY, USA, 1991; pp. 51-94.

11. Chinain, M.; Darius, H.T.; Ung, A.; Fouc, M.T.; Revel, T.; Cruchet, P.; Pauillac, S.; Laurent, D.; Ciguatera risk management in French Polynesia: The case study of Raivavae Island (Australes Archipelago). Toxicon 2010, 56, 674-690, 10.1016/j.toxicon.2009.05.032.

12. Caillaud, A.; de la Iglesia, P.; Darius, H.T.; Pauillac, S.; Aligizaki, K.; Fraga, S.; Chinain, M.; Diogene, J.; Update on Methodologies Available for Ciguatoxin Determination: Perspectives to Confront the Onset of Ciguatera Fish Poisoning in Europe. Mar. Drugs 2010, 8, 1838-1907, 10.3390/md8061838.

13. Pearn, J.; Neurology of ciguatera. J. Neurol. Neurosurg. Psychiatry 2001, 70, 4-84, 10.1136/jnnp.70.1.4.

14. Pasinszki, T.; Lako, J.; Dennis, T.E.; Advances in Detecting Ciguatoxins in Fish. Toxins 2020, 12, 494, 10.3390/toxins12080494.

15. U.S. Department of Health and Human Services Food and Drug Administration Center for Food Safety and Applied Nutrition: Fish and Fishery Products Hazards and Controls Guidance, Fourth Edition - March 2020 . U.S. Department of Health and Human Services Food and Drug Administration Center for Food Safety and Applied Nutrition. Retrieved 2020-8-23

16. Lewis, R.J.; Sellin, M.; Poli, M.A.; Norton, R.S.; MacLeod, J.K.; Sheil, M.M.; Purification and characterization of ciguatoxins from moray eel (Lycodontis javanicus, Muraenidae). Toxicon 1991, 29, 1115-1127, 10.1016/0041-0101(91)90209-A.

17. Pottier, I.; Vernoux, J.-P.; Jones, A.; Lewis, R.J.; Characterization of multiple Caribbean ciguatoxins and congeners in individual specimens of horse-eye jack (Caranx latus) by high-performance liquid chromatography/mass spectrometry. Toxicon 2002, 40, 929939, 10.1016/S0041-0101(02)00088-0.

18. Lewis, R.J.; Vernoux, J.-P.; Brereton, I.M.; Structure of Caribbean Ciguatoxin Isolated from Caranx latus. J. Am. Chem. Soc. 1998, 120, 5914-5920, 10.1021/ja980389e.

19. Estevez, P.; Castro, D.; Manuel Leao, J.; Yasumoto, T.; Dickey, R.; Gago-Martinez, A.; Implementation of liquid chromatography tandem mass spectrometry for the analysis of ciguatera fish poisoning in contaminated fish samples from Atlantic coasts. Food Chem. 2019, 280, 8-14, 10.1016/j.foodchem.2018.12.038.

20. Murata, M.; Legrand, A.M.; Ishibashi, Y.; Fukui, M.; Yasumoto, T.; Structures and Configurations of Ciguatoxin from the Moray Eel Gymnothorax javanicus and Its Likely Precursor from the Dinoflagellate Gambierdiscus toxicus. J. Am. Chem. Soc. 1990, 112, 43804386, 10.1021/ja00167a040. 
21. Yasumoto, T.; Igarashi, T.; Legrand, A.-M.; Cruchet, P.; Chinain, M.; Fujita, T.; Naoki, H.; Structural Elucidation of Ciguatoxin Congeners by Fast-Atom Bombardment Tandem Mass Spectroscopy. J. Am. Chem. Soc. 2000, 122, 4988-4989, 10.1021/ja9944204.

22. Satake, M.; Murata, M.; Yasumoto, T.; The Structure of CTX3C, a Ciguatoxin Congener Isolated from Cultured Gambierdiscus Toxicus. Tetrahedron Lett. 1993, 34, 1975-1978, 10.1016/S0040-4039(00)91978-6.

23. Satake, M.; Fukui, M.; Legrand, A.-M.; Cruchet, P.; Yasumoto, T.; Isolation and Structures of New Ciguatoxin Analogs, 2,3DihydroxyCTX3C and 51-HydroxyCTX3C, Accumulated in Tropical Reef Fish. Tetrahedron Lett. 1998, 39, 1197-1198, 10.1016/S0040-4039(97)10808-5.

24. Yogi, K.; Oshiro, N.; Inafuku, Y.; Hirama, M.; Yasumoto, T.; Detailed LC-MS/MS Analysis of Ciguatoxins Revealing Distinct Regional and Species Characteristics in Fish and Causative Alga from the Pacific. Anal. Chem. 2011, 83, 8886-8891, 10.1021/ac200799j.

25. Satake, M.; Ishibashi, Y.; Legrand, A.-M.; Yasumoto, T.; Isolation and Structure of ciguatoxin-4A, a New Ciguatoxin Precursor, from Cultures of Dinoflagellate Gambierdiscus toxicus and Parrotfish Scarus gibbus. Biosci. Biotech. Biochem. 1997, 60, 2103-2105, 10.1271/bbb.60.2103.

26. Harwood, D.T.; Murray, S.; Boundy, M.J.; Sample Preparation Prior to Marine Toxin Analysis. Compr. Anal. Chem. 2017, 78, 89136, 10.1016/bs.coac.2017.07.003.

\section{Keywords}

ciguatera; ciguatoxin; cytotoxicity assay; ELISA; HPLC; immunoassay; LC-MS/MS; mouse bioassay; receptor-binding assay 